\title{
Journalism as a field of discursive production - performativity, form and style
}

\section{ABSTRACT}

By focusing on the emergence and development of journalistic conventions and professional routines it is possible to understand the prominent role of journalism in the social construction of meaning. In this article, we theoretically examine journalism as a special field of discursive production. The field of journalism presents more than the facts it gathers and reports. The institutionalized retelling of events is a very distinct way to put meaning on them. We suggest journalism is a historically and culturally bounded discourse whose performative nature is at the core of its moral authority and social credibility. In addition, the performative discourse of journalism invites us to extend the concept to include, for example, the conventions of style and form. The historical transformations journalism took may, thus, be looked at as efforts in the battle for performative discourse involved in the process of a mimetic (re)construction of the social world.

A popular government without popular information, or the means of acquiring it is but a prologue to a farce or a tragedy: or, perhaps both. Knowledge will forever govern ignorance: And a people who mean to

\section{KEYWORDS}

media history discourse journalism performativity style form 
1. The sentence was coined by English author Edward BulwerLytton, in 1839, in his play Richelieu; Or the Conspiracy. be their own Governors, must arm themselves with the power which knowledge gives.

(Madison [1822] 1900: 103)

\section{INTRODUCTION}

We are well aware of how words have such an unbelievable power to move us. And journalism as an art of storytelling capitalizes just that. 'The pen is mightier than the sword' is an adage that an independent press is more effective than violence ${ }^{1}$. And usually we do not assume journalism to have the power to change the world, nor what we think, but mostly the way we think about social issues (agenda-setting function). One might even say, alluding to Madison's quote, that the power of journalism lies in the knowledge it gives. Michael Schudson (1995: 54) suggests that its power comes from the ability to provide the forms in which things are declared to be true. In fact, journalism acts as a kind of social mediator: it functions as an intermediary between the public and the policy-making elites. Lippmann (1922) claimed that the public was incapable of assessing all the growing storm of facts and complexity of the social world, so the public needed journalists to filter the news, distil the facts and arrange them for public consumption.

If newspapers work as social maps (Broersma 2007: x), we need to deepen our understanding of how they construct meaning and articulate social worlds. By focusing on the emergence and development of journalistic conventions and professional routines - and also by studying journalism history - we may start to deal with that endeavour. Exposing cultural and ideological values and viewing them from a historical perspective helps us to understand how journalism came to assume such a prominent role in today's societies. When Schudson (1995: 71) talks about the politics of the narrative form, he is especially interested in emphasizing that to understand media we must also understand the substantial authority of the journalistic narrative form.

Yet, media history or journalism history studies tend to concentrate on institutional contexts to examine journalism, aiming to detect the organizational, political, technological and economic aspects of the press. Actually, the business model of the newspaper, the structure of ownership and editorial restraints have been extensively examined. Mainly, the relationships between press, government and society, as well the connections to the public sphere, have been subject to an intense scrutiny (Schudson 1998; Ryfe 2006; Asp 2007; Meadows 2013; Peters et al. 2015). On the other hand, journalism historiography (Salmon [1923] 1976; Nord 1990) has concentrated on, among other themes, two axes: narratives of the newspapers doing biographies of a particular editor or remembering its main events (Nevins 1959); and a quantitative approach (Pauly 1989) for content analysis. These two approaches to journalism history are fragile because they tend to privilege the professional practice of journalism instead of how society relates to what the newspaper tells about the world. Thus, identifying its themes and topics does not explain how they connect and are appropriated by the public and social organizations.

James Carey $(1974,2007)$ was one of the first to precisely react to a press history exceedingly (and exclusively) preoccupied with the structures of ownership and control, rights and freedom, editorial organization and routine activities. 
This views journalism history as the slow, steady expansion of freedom and knowledge from the political press to the commercial press, the setbacks into sensationalism and yellow journalism, the forward thrust into muck raking and social responsibility [...] the entire story is framed by those large impersonal forces buffeting the press: industrialization, urbanization and mass democracy.

(Carey 1974: 3-4)

He argued that press historians had defined the craft too narrowly and too modestly. Already in 1945, Sidney Kobre advanced the notion of studying the relationships between the newspaper and society by analyzing the interactional factors that caused the press to develop and to change in time. A cultural approach would then not just take the institutional dimension but also focus on the 'history of reporting' (Carey 1974: 4).

In this article, we take this cultural approach to press history and study the narratives of journalism. In other words, we want to examine the construction of social meaning by viewing journalism as a specific field of discursive production. Newspapers present more than the facts they gather and report. They have discursive norms that had (and still have) a radical importance in the automatization and routinization of the profession. In effect, the use of conventions of form and style is not simply a question of identity and marketing segmentation. 'While the content of news changes every day, form and style assure the ritual function of news' (Broersma 2007: ix). We endorse Broersma (2007) when he credits form and style as essential in making people believe in the 'truthiness' of the events. He argues (Broersma 2010: 16) that journalism derives its performative power from the forms and style employed through which it imposes and legitimizes valid representations of the social world.

We do not reduce journalism discourse to news discourse (Van Dijk 1988) since it is just a possible manifestation of journalism discourse. It is this journalism discourse that people accept to see what happens in the world. And it is its credibility that makes individuals recognize the mediating function of journalism. By studying journalism discourse, we can take news to the level of society and deepen our comprehension of the historical emergence and affirmation of journalism as a discursive field.

We will start by characterizing journalism discourse as a culturally discursive genre. Then, we describe journalism as a performative field of discursive production. The article ends by considering the enlargement of the notion of journalism discourse and suggests that one needs to consider style and form in order to deal with this kind of multifaceted and complex discourse.

\section{JOURNALISM DISCOURSE - A CULTURALLY MARKED DISCURSIVE GENRE}

Media historians frequently assume that journalism is a creation of seventeenth-century Europe when the first journals appeared (gazettes, libels, etc.). For example, Stephens (1988: 156) credits the Venetian gazettes of the second half of the sixteenth century as the precursors of journalism. Yet, if we pay close attention to the sequence of developments in journalism in America, Britain and France, we may feel that there is an Anglo-American precedence. Chalaby (1996a) argues, for example, that journalism is specifically an AngloAmerican invention. American and British journalists 'invented' the modern 
2. 'No mail yesterday'. This was what the editor of the Orleans Gazette wrote, in 1805 At this time, editors obtained a substantial part of their news waiting for the post to bring out-of-town newspapers and letters (Stephens 1997). conception of news, had better organized news-gathering services and were the first to impose a set of proper discursive practices that were then progressively imported and adopted by many other countries since the eighteenth century.

This signifies that the emergence of journalism is not only historically marked, but also culturally marked (Chalaby 1996a: 304). The discursive transformation of journalism did not occur spontaneously in each country. Instead, it may be claimed that it was in the United States and, to a lesser degree in England, that journalism's discursive strategies were first defined and that an autonomous field of discursive production emerged. And that other nations, like France (Ferenczi 1993), progressively adopted the seminal methods of Anglo-American journalism. In fact, information was more recent, international, exact, complete and frequent in American and British newspapers than in French ones. In part, this was due to the growing industrialization process, the technological innovation in newsprint (production, printing and distribution), but also to the spread of literacy and the growing of mass democracy, urbanization and consumer society. Economic motives also played their part, namely, the existence of an advertising market. For first time, newspapers depended on their own revenues. This financial independence was a major contributor to the depolitization of journalists' discursive practices and encouraged the development of a journalism of information based on neutrality and objectivity (Chalaby 1996a: 320). 'Anglo-American press owners, editors, and journalists did not simply devote important resources to collect information from local, national and international sources, they also invented discursive practices designed to collect and report this information' (Chalaby 1996a: 310).

According to Chalaby, 'the profession of the journalist and the journalism discourse is the product of the emergence, during this period, of a specialized and increasingly autonomous field of discursive production, the journalistic field' (1996a: 304, original emphasis). Gradually, the journalism discourse became a distinctive class of texts, developing its own discursive norms and values and particular discursive strategies and practices (Chalaby 1998: 32-54). These discursive practices had not a political character nor a literary one. In fact, these genres were in constant tension with journalism since the beginning (cf. Ferenczi 1993). Journalism texts began to possess distinguishing philological characteristics that gave a discursive identity to it. One of the main characteristics of journalism's discursive practices has to do with a fact-centred discourse in which reporting, interviewing and objective writing play a key role.

First, the news report format was an effort to produce information and not just wait for it. ${ }^{2}$ But, above all, reporting led to the dissociation between facts and opinions, which began to be separated into two distinct journalistic genres: the newspaper article and the editorial. Value judgements did not simply vanish, but they tended to be limited in reporting. News reports first put in place the facts, and are built on facts and dwell on facts, not on 'ideas or chronologies' (Stephens 1988: 253). The narrative form is, thus, organized around facts and are not opinion-orientated. They tend to put aside interpretations, although interpretative observation tends to be always present. The reporting is inspired by an informational model of discourse in which journalism aims to provide news to citizens in order for them to be informed participants in democracy. This means facts are given in a non-partisan way in order to ensure a (hopefully) neutral perspective on social reality. 
Second, the fact-centred discourse of journalism has also developed from interviewing. 'By the turn of the century, the interview was the central act of journalism' (Schudson 1994: 565). On the turn from the eighteenth to the nineteenth century, interviews were much more common in American and British newspapers than in French ones. French politicians were more reluctant to give interviews and preferred to write their own public interventions (Chalaby 1996a: 312). Interviewing came to be a major practice for an emerging profession aspiring to be recognized as an autonomous field of discursive production. It encouraged journalist's selfconfidence because they were in complete control. They asked the questions and wrote the answers in an exercise of full autonomy. The interview was also a way to gain professional status (Broersma 2007: xxvii) and a means to self-representation. Unlike newspaper articles, where journalists are practically invisible to the reader, interviews emphasized precisely the journalist. While articles were left unsigned and the discursive voice presupposed the concealment of the journalist, in interviews journalists were clear visible actors with their names mentioned and their authority and competence to ask fully acknowledged. Hence, interviewing opened an opportunity to highlight a professional class and display individual merits by asking intellectually stimulating questions.

Objectivity is the third key component of the fact-centred journalism discourse, which emerged in the late nineteenth century. Until then, newspapers reflected the point of view of the publisher or editor (Stephens 1997: 11) and formed an opinion press. But as mass circulation transformed newspapers into profitable businesses, they started to assume the role of providers of information. As positivism in science and realism in literature became popular, journalism developed into an art of factual news-stories. In consonance with those major influences, journalism discourse reduced the emphasis on the particular and personal opinion in favor of a more objective, impartial and detached approach. Objectivity entailed the conviction that events should be treated as pure facts, as raw data that could be transposed into the newspaper article without corruption. Objectivity became the moral norm for reporting and, by the 1920s, was firmly established as the leading norm in the United States (Williams 2006).

In effect, the focus on objectivity obeyed the necessity of journalism to distinguish itself from other influential communication activities such as propaganda and the public relations industry. This veneration for facts was a great impulse to the spread, after the American Civil War, of the inverted pyramid writing style in which facts of an event were narrated from the most important to the least important ones. The inverted pyramid contributed to the affirmation of journalism with its own professional standards and discursive practices. It balanced popular appeal with professional authority. At the same time, it answered the need to fulfil the social function to inform, with the need to inform in a proper and autonomous discursive practice. Moreover, the inverted pyramid technique and the objectivity norm supplied a set of easy to follow rules that facilitated the process of professional 'indoctrination' and standardized journalistic writing (cf.Van Hout 2015).

This short retrospective does not mean we are reducing the evolution of journalism discourse to a dualistic dispute between Anglo-American discursive norms and other European (French, for instance) traditions. After all, there is no such dichotomy. Journalism can be seen as a social field: it comes not without constitutive strains - concomitant or antagonistic. These tensions 
delineate a field composed by a multiplicity and plurality of discursive practices (Mesquita 2003: 185). In other words, journalism as a social field has evolved historically, reflecting several tensional appropriations or rejections of the Anglo-American discursive pattern. What we simply wanted to stress is that the Anglo-American journalism discourse is a universal reference to the practice of the profession (Williams 2006: 44).

This supposes that the discursive practice of journalism had several stages that assimilated, changed or resisted the Anglo-American norms. Some authors raise doubts about the complete prevalence of these cultural norms in Europe. For example, by proposing a conceptualization of journalism culture consisting in institutional roles, epistemologies and ethical ideologies, Hanitzsch (2007) contributed to signalling the importance of considering different cultural norms in journalism's evolution. Some authors prefer to talk, for instance, in a European model of journalism (Williams 2006: 58). In consonance with this, Papathanassopouolos (2001: 507) argues that, in the Greek case, it is not possible to envisage a journalistic culture faithful to the Anglo-American model. In Portugal, some works have pinpointed the dichotomy between a politically engaged opinion press and an apolitical press (Tengarrinha 1971; Baptista 2012; Barros 2014). Some of them stressed the singularities that characterized the gradual (and sometimes partial) adoption of the Anglo-American model. And in Spain, Fernández del Moral and Esteve Ramírez (1996), as also Canel Crespo and Piqué Fernandez (1998), bring us interesting insights about some resistances to the universality that characterizes the Anglo-American model. Alonso and Meier (2012: 248) conclude that, even though Anglo-American journalistic discourse - specifically objectivity - can be observed in today's Spanish journalism, there are some nuances: they point to the ambiguity of the answers that constitute their qualitative enquiry, more exactly, what may be understood by objectivity and the methods to attain it.

Some comparative studies show the dialectical tensions between the discursive patterns in different countries (Deuze 2002; Berganza Conde and Hanitzsch 2011). One of most pertinent of these works is perhaps Halin and Mancini's Comparing Media Systems (2004). The authors demonstrate the importance of economic and political contexts in the configuration of journalistic praxis. They also underscore a fundamental discrepancy: how theory and practice, normative ideals (what journalism should be) and factual occurrences (what journalism is), are sometimes completely apart. That is why Joesphi (2005: 576), disserting about the normative and the empirical journalism in a global age, suggests that Anglo-American discursive practices should be considered, above all, as a guiding principle of modern journalism that comes not without exceptions.

In sum, we should consider that journalistic discourse presents dissimilar developments across different countries. Despite the centrality of the Anglo-American discursive standards, we have just seen how a more nuanced perspective serves us better in the evaluation of the journalism discourse development. Journalism is culturally bounded: this means the Anglo-American discursive pattern is crucial to modern journalism; however, we should not neglect how different historic and cultural traditions have adopted it.

Having pointed out the fundamental attributes of the culturally marked journalism discourse, we proceed to characterize it as a performative field of discursive production. 
JOURNALISM - A PERFORMATIVE FIELD OF DISCURSIVE PRODUCTION

How could one describe this specific field of discursive production?

This is a question many have addressed from the point of view of the factcentred, Anglo-American paradigm of news. We will now approach the journalistic discourse through a performative perspective. Following Broersma (2010: 16), we argue journalism is a discourse that is characterized, above all, by its performative nature.

Journalism's performativity may be better seen through two different layers: as a pragmatic activity, and as an enactment of its discourse.

Journalism entails a performative discourse because it is not a simple description or report of reality. It is a special way to regard events and personalities and it is reinforced by the performative nature of language. Therefore, since journalism is a linguistic activity, it may be considered as performative. To say something is to do something (Austin 1962). But journalism is also a discourse that restages or performs social reality. It is also an action imposed on social reality, a kind of lens ${ }^{3}$ through which the world is offered to be seen. Journalism has, thus, a double performative nature composed by these two juxtaposed layers.

Let us begin with the first layer: journalism's discourse is performative, given that it functions pragmatically as an action upon the world. Journalism is a field where expressive functions tend to prevail over the pragmatic ones (Rodrigues 2001: 158). First of all, journalism acts on the discursive structure of societies. This pragmatic function means that journalism does something by just describing it (e.g., think on the media visibility of social issues). It reflects the world, but that reflection is also a reflective act capable of negotiating meanings.

We can see that this pragmatic layer is very close to the second layer of performativity indicated above: an enactment of discourse. Retelling events is already to put meaning on them. The performative nature of journalism's discourse, in this second sense, has to do with the role journalism plays as 'meaning-broker in modern society' (Matheson 2000: 571). To effectively do this, it has to convince the public that what was written and broadcasted has actually and really happened as reported. Yet, this persuasive action trying to put reality beyond discourse is doomed to be incomplete. Discourse is, of course, a symbolic barrier between the public and authentic reality.

One of the main forms of meaning negotiation lies precisely in the performative dimension of journalism's discourse. We encounter the second sense of journalism's performativity when it tries to erode the symbolic barrier between speech and reality, and hide its shortcomings. Journalism is performative when its discourse enacts itself trying to present 'facts' as natural (live broadcasts are a perfect example of this) and, at the same time, concealing its distance from reality through discursive procedures aiming to prove them as truthful. For instance, interviews are structured around questions and answers mimicking the conversational flow of dialogues. And they are chronologically organized. Nonetheless, its elusive enunciation does not eliminate the discursive procedure that tries to cover up the fact that the interview is an interpretation of a conversation (Broersma 2010: 17).

To ensure an effect of authenticity, truthfulness, facticity and objectivity, journalistic texts rely on a set of discursive procedures, textual conventions and professional routines developed in the Anglo-American turn from the
3. This alludes to Bourdieu: 'Journalists have special "glasses" through which they see certain things and not others, and through which they see the things they see in the special way they see them' (1998: 19). 
nineteenth to the twentieth century that has the very objective to provide a representation of the social world that is as accurate as possible. The performative field of discursive production that is journalism tries to bind representation to reality, eroding all the discursive mechanisms that do not reduce the distance between the public and the portrayed. So, outside the editorial, we rarely see the journalist pronouncing himself as a subject or an individual subjectivity in order to ensure there is a mimetic effect between what he (re) presents and what is actually happening.

This second layer of journalism's performative discourse is of the utmost importance. To say journalism is a performative activity means that its self-asserted authenticity, truthfulness, facticity and objectivity, as discursive norms, must always be re-enacted. Journalism as a discursive field (cf. Richardson 2007) is only real to the extent that its own conventions, procedures and routines are constantly performed. The social construction of the world that journalism preconizes is based on the performative nature of its discourse in which authenticity, truthfulness, facticity and objectivity do not exist per se. Instead, they are the result of a careful and willful work upon a discursive construction. There is no objectivity without a discursive appropriation of what 'objective' may be expected to signify in journalism. Objectivity neither precedes nor follows performativity. It is only through performativity that the discursive field of journalism can be recognized as a truthful discourse on reality. In other words, performativity makes possible that journalism plays its role of discursive production about the world.

Being performative just means that journalism discourse is a kind of stylized repetition of acts that enacts the formal conventions through which we postulate it as an objective and factual reporting of the world. Hence, to consider journalism as a field of discursive production involves the realization or enactment of something that actually does not exist before it is performed.

The performative nature of journalism discourse gives us a new perspective on the truth claims while it assumes the representation of reality as a social construction. It does not mean that journalistic texts mirror reality; it means that journalism discourse is forged in the claims to represent reality. It is a discursive procedure to ensure journalism is a discourse of its own, with its pretensions to be regarded as legitimate. 'Every day journalism stages the social world in language. Every day its authority has to be reconfirmed. Millions of people take part in this large-scale ritual of meaning-making undertaken by the media' (Broersma 2010: 19).

In fact, the performative nature of journalism is essential to its status and position in society. In a sense, the legitimate competence that western societies recognize in journalism is anchored in its own performative capacity to be effectively identified with a field of discursive production (Van Hout et al. 2012) that can be successfully linked to what it claims to represent.

Therefore, journalism discourse is not just a textual representation of events: it is primarily a performative exercise of symbolic power.

Let us take, for example, the case of the newscast. The enunciative devices employed are intended to guarantee the universal recognition and validity of journalism discourse despite all the differences between audience members, the public or involved social actors. As Dunn (2005: 140) states,

the characteristic visual and audio codes and narrative structures of television news work together to construct such news values as truth and balance, as well as to convey authority and immediacy. It is important to 
realize that news comprises a set of formal conventions of representation and narration that together shape a view of 'reality', and television news is one of the most conventionalized formats of the medium.

Ultimately, it is the performative nature of journalist discourse that helped it to establish a reputable, credible and autonomous social field. Journalists have held themselves together as a corporative group (mechanisms of education, professionalization) but also as an interpretative community (Zelizer 1993) with its own beliefs, narratives and everyday activities. In fact, this performative nature of discourse aided journalists in developing a discourse and a knowledge of their own that evolved into an interpreter capable of reordering the multiple fragments of social experience in a meaningful whole.

In order to deepen this performative power, we will, next, discuss two central categories in journalistic discourse.

\section{JOURNALISTIC DISCOURSE AS A CLASS OF TEXTS: FORM AND STYLE}

We have posited that journalism is a historically and culturally marked notion. We have also underscored its discursive performativity. Now, we want to expand the notion of journalism discourse beyond the news discourse. In fact, in order to understand performativity, we must regard journalism discourse from a wide perspective comprising not just texts but special classes of text, a set of texts with discursive properties including specific norms and values. Defined in this way, discourse can be used to refer to a multifarious but concrete object: classes or types of texts produced by real social agents in specific socio-historical conditions (Chalaby 1996b: 696).

This does not mean that the linguistic dimension of discourse is subsumed. Yet, it puts the linguistic aspect in a more relative, not absolute, position. In the first section we were already confronted with journalistic discourse as a class of texts when we referred to the news-reporting, for example. And by situating it in a historical and cultural period of time, we were already demonstrating a simple thing: discourse is also a sociological concept. This is why Chalaby (1996b) suggests that discourse, as a class of texts, is indeed a sociological object. Discourse is a socio-historical entity whose efficacy is purely symbolic. Language is the means by which the discourse manifests itself. It means the revelation of discourse; it is, in the words of Chalaby, a 'discourse-phenomenon' (1996b: 697). But from this it does not follow that we must obliterate discourse's socio-historical dimension in favour of its linguistic facet.

We are now in a better condition to contend that the journalistic discourse is the class of texts produced by social agents in the journalistic field (Cotter 2010). And given its socio-historical inscription as well as its performative nature, journalism as a field of discursive production is always involved in the battle to define its own discursive genre. From there, it results different discursive strategies (including sensationalism) that are constantly put into action for journalism, as a discursive field, to gain authority. These discursive strategies are also important to stabilize journalism's own performativity. The public is not able to determine the truth conditions of the newspaper article. Yet, it may consider it as true because it seems plausible. Or, this plausibility comes not just from the continuous exercise of cultural codes and public knowledge, but also from the discursive procedures the newspaper article enacts to the point where the journalist can successfully argue it is true. Journalism claims that composing its own discursive genre is dependent on 
an effective discursive strategy and a successful definition of journalism as a field of discursive production.

At this point, and having in mind that discourse is a class of texts, we must enlarge the conception of journalism discourse. The performative power of a text does not only lie in its content (texts) but also in the articulation and negotiation of its contents (classes of text). As argued by Broersma,

the performative power of a text not only lies in its content but chiefly in its form and style - this is, in the expression of professional routines and conventions that justify, and mask, the subjective interpretations and news selection of the individual journalist.

(2010: 20)

In other words, the performative power of journalism discourse dwells not just in linguistic texts but in multimodal texts and in the discursive procedures journalism takes to guarantee its own authority in the reporting of the world.

We must, then, take into account form and style as key components of journalistic discourse that, in a given time, are able to generate credibility and confidence. Beyond the content of a journalistic piece (which is unique and somewhat unrepeatable), form and style refer to broader cultural discourses and widely accepted news conventions and discursive norms (Broersma 2010: 20). Content may vary from day to day, but readers will recognize the newspaper design, writing style (Perrin 2013) and ideological background from the linguistic and extra-linguistic discourse it presents.

This is why form and style, as key components of journalism discourse, are essential to journalism performativity: they are crucial aspects in the respectability and reliability of newspapers.

Conventions of form and style have a major contribution to the public's belief that its representation of the world is valid. Journalism discourse's performativity is, then, related to these discursive conventions of form and style that determine how stories are told and, by doing it, determine how we experience the world. "The power of media lies not only (and not even primarily) in its power to declare things to be true, but in its power to provide the forms in which declarations appear' (Schudson 1995: 109). Indeed, the prestige of journalism depends on the performative force of its discursive practices.

Conventions of style have to do with the choice between functionally equivalent elements of language. It refers to practices and routines that display the journalist identity - what news is and how the journalist should act towards it (Broersma 2007: xiii). Stylistic routines (Tereszkiewicz 2012) offer an ideological framework determining what is valuable, what should be included or excluded and what to expect from the story. In sum, style is a specific way of talking about the world that underlies social meanings commonly shared in the discursive field, including particular sociolects (Miller 1962). Modern press has primarily been functioning through two main news styles: the information model associated with reference newspapers, and the story model associated with a sensationalist discursive strategy and more popular newspapers. News values are worked upon conventions of style: the same news value (e.g., death) is an object of a separate discursive activity. Styles are not exclusive terms: they may coexist in the same journalistic product. Informational and story models of style are two possible exercises in journalism's discursive production (cf. Broersma 2007: xiv) but many more could be identified. 
Conventions of form are the visible part of the conventions of style. 'A newspapers' style is articulated by the forms it uses to present the social world to its readers' (Broersma, 2007: xxiii). Form appeals to the conventions in texts, illustrations, layout, graphical elements or design genres, as well as those visual schemes that separate different thematic divisions.'Form is everything a newspaper does to present the look of the news' (Barnhurst and Nerone 2001: 3). Conventions of form are more exposed to technological and economic developments as well as sociocultural factors. Innovations in typesetting and printing made possible the inclusion and editing of photographs, columns and headlines, which corresponded with other modes to frame the news content in journalism discourse. Form is the performative element that appeals the most to the public's desire and expectations and is one of the first things a reader takes into account when choosing a singular newspaper among many others (cf. Smith and Higgins 2013).

It also easy to confirm the importance of form conventions to journalism: the structure and length of an article reveals, in fact, ideological choices. And the space that a piece occupies may be a significant indicator of the importance editors attach to it. ${ }^{4}$ This is a primordial aspect concerning journalism's discursive performativity since it is not hard to imagine that the reader will tend to feel that newspapers giving more attention to the event could provide a more accurate representation of it. The simple negotiation of the convention of form, as this example demonstrates, may have crucial implications in the performative discourse around immediacy, truthfulness and objectivity as discursive norms.

In sum, to study journalism as a field of discursive production one must take into account a multimodal approach to discourse that encompasses the conventions of style and form. We must expand the concept of discourse from a restricted notion of a linguistic happening to a more widening notion that includes visual, non-linguistic and semiotic elements.

Journalism's performativity is, thus, not subsumed in a socio-historical context but is a working-in-progress notion. It requires looking into discourse from a sociological standpoint and taking it as a class of texts or a system of discursive norms, conventions and routines that function as a whole demanding the recognition of authority and credibility of journalism as a professional community and social field.

\section{CONCLUSION}

The style and form of journalistic discourse affect the understanding of reality and influence how subjects are discussed - in what terms, its values, its consequences. The interpretation of events made by journalists should, hence, be considered in the light of strategic discursive practices that contribute to performing the claims that distinguish journalism from other discursive productions. Its moral authority is part of this process of a performative discourse that gives them social power.

This approach supposes that societies are shaped by the representations of the social world, and that journalistic representations are part of that general discursive process. If, as stated, journalism functions as a cognitive social map, it may be because it constructs social meaning and articulates the common world. In this process, journalism discourse plays an eminent role. To understand journalism, we need, first, to understand how discourse affects the representation of reality and how discursive procedures are a
4. A simple example comes from the 2016 UEFA European Championship and the total space newspapers gave to the event's final game. It is not a surprise that two Portuguese sports newspapers devoted the front page and back page to the victory of the Portuguese team, while in other countries, such as Spain, newspapers dedicated much less space to the occurrence in their front pages 
5. In every society, the production of discourse is at once controlled, selected, organized and redistributed by a certain number of procedures whose role is to ward off its powers and dangers, to gain mastery over its chance events and to evade its ponderous, formidable materiality (Foucault 1981: 52). fundamental aspect of the credibility and moral authority journalism enjoys.

Ultimately, the ways in which discourse is arranged 'depends on sociocultural modes of expressing experience' (Rodriguez 2004: 150). But one must also acknowledge that the social-cultural representation of experience is indeed possible because we have a set of pre-existent discursive parameters. Those parameters may be regarded as being restrictive and obstructive. However, those same parameters are the elements that make possible the discursive process about the world. There is, thus, a dynamic influence between the world, representations of the world and the discourse about the world. One can only say what is possible to say at a given moment. ${ }^{5}$ The order of discourse (Foucault 1971) gives rise to an ordering of the social experience.

By focusing on the journalism discourse, we wanted to emphasize how this field of discursive production participates in the ordering and enactment of the social experience. And how the inherent performative nature of journalism discourse contributes to reinforcing that intrinsic ordering of the word that discourse imposes.

In this article, we tried to describe the field of journalism discursive production as a performative one and to retain some consequences of this situation. Journalism constitutes a historically and culturally marked discourse whose performative power reinforces the role of journalism as a central player in the social construction of the world. To say that journalism constitutes a historically and culturally marked discourse does not mean it is not truly important nowadays. On the contrary, this attribute only strengthens the need to consider how performativity is something that never ends. It is through performativity that the journalism, as a field of discursive production, can be always be self-affirmative, always struggling to be a moral authority and always claiming to be a truth discourse.

At the end of the article we adopted a sociological point of view and extended the conception of discourse to a class of texts that need to be examined from a multimodal standpoint. This should make us consider the role conventions of form and style play in the construction of journalism discourse. They are very important aspects in the capacity to build trust, reliance and confidence in the public because they do not only distinguish different newspapers among them, but also help to distinguish the journalism discourse from many other types of social discourses (e.g. public relations).

Overall, we may say journalism is a self-evolving discursive activity whose performativity involves social conventions including style and form. The historical transformations it took may, thus, be seen as efforts in the battle for the authenticity, objectivity and truthfulness effect. Little moments in the performative journey around the discursive practices that are involved in the process are a mimetic (re)construction of the social world.

\section{REFERENCES}

Alonso, Martín Oller and Meier, Katrin (2012), 'La idea de objetividad de los periodistas dentro de la cultura periodística de España y Suiza', Estudos em Comunicação, 12, pp. 223-53.

Asp, Kent (2007), 'Fairness, informativeness and scrutiny: The role of news media in democracy', Nordicom Review, 28, pp. 31-49.

Austin, John (1962), How to do Things with Words: The William James Lectures delivered at Harvard University in 1955 (eds J. O. Urmson and Marina Sbisà), Oxford: Clarendon Press. 
Baptista, Carla (2012), Apogeu, Morte e Ressurreição da Política nos Jornais Portugueses - do Século XIX ao Marcelismo, Lisboa: Escrit'orio.

Barnhurst, Kevin and Nerone, John (2001), The Form of the News: A History, London: Routledge.

Barros, Júlia (2014), ‘O Jornalismo político Republicano Radical. O Mundo (1900-1907)', Ph.D. thesis, Lisbon: Faculdade Ciências Sociais e Humanas, Universidade Nova de Lisboa.

Berganza Conde, M. R. and Hanitzsch, T. (2011), 'Trust in public institutions among journalists: Comparative evidence from 18 countries', Conference of the ECREA Political Communication Section, Madrid, 20-21 October.

Bourdieu, Pierre (1998), On Television, New York: New Press.

Broersma, Marcel (2007), 'Form, style and journalistic strategies: An introduction', in M. Broersma (ed.), Form and Style in Journalism. European Newspaper and the Representation of News, 1880-2005, Leuven: Peters, pp. ix-xxix.

— (2010), 'Journalism as performative discourse: The importance of form and style in journalism', in Verica Rupar (ed.), Journalism and MeaningMaking: Reading the Newspaper, Cresskill, NJ: Hampton Press, pp. 15-35.

Canel Crespo, M. J. and Piqué Fernandez, A. M. (1998), 'Journalists in emerging democracies: The case of Spain', in D. H. Weaver (ed.), The Global Journalist. News People Around the World, New Jersey: Hampton Press, pp. 299-319.

Carey, James W. (1974), 'The problem of journalism history', Journalism History, 1:1, pp. 3-5, 27.

_ (2007), 'A short history of journalism for journalists: A proposal and essay', Press/Politics, 12:1, pp. 3-16.

Chalaby, Jean K. (1996a), 'Journalism as an Anglo-American invention: A comparison of the developments of French and Anglo-American Journalism, 1830s-1920s', European Journal of Communication, 11:3, pp. 303-26.

_ (1996b), 'Beyond the prison-house of language: Discourse as a sociological concept', The British Journal of Sociology, 47:4. pp. 684-98.

(1998), The Invention of Journalism, London: Palgrave Macmillan.

Cotter, Colleen (2010), News Talk: Investigating the Language of Journalism, Cambridge: Cambridge University Press.

Deuze, Mark (2002), 'National news cultures: A comparison of Dutch, German, British, Australian, and U.S.', Journalism and Mass Communication Quarterly, 79:1, pp. 134-49.

Dunn, Anne (2005), 'Television news as narrative', in R. Huisman, J. Murphet and A. Dunn (eds), Narrative and Media, Cambridge: Cambridge University Press, pp. 140-51.

Ferenczi, Thomas (1993), L'invention du journalisme en France, Paris: Pion.

Fernández del Moral, Javier and Esteve Ramírez, Francisco (1996), Fundamentos de la Información Periodística Especializada, Madrid: Editorial Síntesis.

Foucault, Michel (1981), 'The order of discourse' (trans. Ian McLeod), in R. Young (ed.), Untying the Text: A Poststructuralist Reader, Boston: Routledge and Kegan Paul, pp. 48-78.

Hallin, Daniel and Mancini, Paolo (2004), Comparing Media Systems: Three Models of Media and Politics, Cambridge: Cambridge University Press.

Hanitzsch, Thomas (2007), 'Deconstructing journalism culture: Toward a universal theory', Communication Theory, 17:4, pp. 367-85.

Joesphi, Beate (2005), 'Journalism in the global age: Between the normative and empirical', Gazette: The International Journal for Communication Studies, 67:6, pp. 575-90. 
Kobre, Sidney (1945), 'The sociological approach in research in newspaper history', Journalism Quarterly, 22 :1, pp. 12-22.

Lippmann, Walter (1922), Public Opinion, New York: Harcourt, Brace.

Madison, James ([1822] 1900), 'James Madison to W. T. Barry', 4 August, in Gaillard Hunt (ed.), The Writings of James Madison, 9, pp. 103-09.

Matheson, Donald (2000), 'The birth of news discourse: Changes in news language in British newspapers, 1880-1930', Media, Culture \& Society, 22:5, pp. 557-73.

Meadows, Michael (2013),'Putting the citizen back into journalism', Journalism, $14: 1$, pp. 43-60.

Mesquita, Mário (2003), O Quarto Equívoco. O Poder dos Media na Sociedade Contemporânea, Coimbra: MinervaCoimbra.

Miller, Carl G. (1962), Modern Journalism, Holt: Rinehart and Winston.

Nevins, Allan (1959), 'American journalism and its historical treatment', Journalism Quarterly, 36:4, pp. 411-22, 519.

Nord, David Paul (1990), 'Intellectual history, social history, cultural history... and our history', Journalism Quarterly, 67, pp. 645-48.

Papathanassopouolos, Stylianos (2001), 'Media commercialization and journalism in Greece', European Journal of Communication, 16, pp. 505-21.

Pauly, John J. (1989), 'New directions for research in journalism history', in Lucy Shelton Caswell (ed.), Guide to Sources in American Journalism History, New York: Greenwood Press, n.pag.

Perrin, D. (2013), The Linguistics of Newswriting, Amsterdam: John Benjamins.

Peters, Frank, van Kleef, Emmy, Snijders, Roxanne and van den Elst, John (2015), 'The interrelation between business model components: Key partners contributing to a media concept', Journal of Media Business Studies, 10:3, pp. 1-22.

Richardson, J. E. (2007), Analysing Newspapers: An Approach from Critical Discourse Analysis, Houndmills: Palgrave.

Rodrigues, Adriano Duarte (2001), Estratégias da Comunicação, Lisboa: Editorial Presença.

Rodriguez, Maria Jose G. (2004), 'Between narrative and non-narrative: Make up of the news story', Revista Canaria de Estudios Ingleses, 49, pp. 135-56.

Ryfe, David (2006), 'News, culture and public life: A study of 19th-century American journalism', Journalism Studies, 7:1, pp. 60-77.

Salmon, Lucy Mainard ([1923] 1976), The Newspaper and the Historian, New York: Octagon Books. Rpt. New York: Oxford University Press.

Schudson, Michael (1994), 'Question authority: A history of the news interview in American journalism, 1860-1930's', Media, Culture \& Society, 16:4, pp. 565-87.

— (1995), The Power of News, Cambridge, MA: Harvard University Press.

- (1998), The Good Citizen: A History of American Civic Life, New York: Free.

Smith, Angela and Higgins, Michael (2013), The Language of Journalism: A Multi-Genre Perspective, London: Bloosmbury.

Stephens, Mitchell (1997), 'History of newspapers', Collier's Encyclopedia, New York: Crowell, Collier and Macmillan, https://www.nyu.edu/classes/ stephens/Collier\%27s\%20page.htm. Accessed 11 April 2018.

(1988), The History of News, New York: Viking.

Tengarrinha, José (1971), História da Imprensa Periódica Portuguesa, Lisboa: Portugália Editora.

Tereszkiewicz, Hanna (2012), 'Lead, headline, news abstract: Genre conventions of news sections on newspaper websites', Studia Linguistica Universitatis Iagellonicae Cracoviensis, 129, pp. 211-24. 
van Dijk, Theun A. (1988), News as Discourse, Hillsdale, NJ: Lawrence Erlbaum Associates, Inc.

van Hout, T. (2015), 'Between text and social practice: Balancing linguistics and ethnography in journalism studies', in J. Snell, S. Shaw and F. Copland (eds), Linguistic Ethnography: Interdisciplinary Explorations, London: Palgrave Macmillan, pp. 71-89.

van Hout, T., Pounds, G. and Vertommen, B. (2012), 'Analyzing the view from here, there and nowhere: Discursive approaches to journalistic stance', Discourse, Context \& Media, 1:2\&3, pp. 55-56.

Williams, Kevin (2006), 'Competing models of journalism? Anglo-American and European reporting in the information age', Journalistica, 2, pp. 43-65. (2007), 'Anglo American journalism: The historical development of practice, style and form', in M. Broersma (ed.), Form and Style in Journalism. European Newspaper and the Representation of News, 1880-2005, Leuven: Peters, pp. 1-26.

Zelizer, Barbie (1993), 'Journalists as interpretive communities', Critical Studies in Mass Communication, 10:3, pp. 219-327.

\section{SUGGESTED CITATION}

Mateus, S. (2018),'Journalism as a field of discursive production - performativity, form and style', Catalan Journal of Communication \& Cultural Studies, 10:1, pp. 63-77, doi: 10.1386/cjcs.10.1.63_1

\section{CONTRIBUTOR DETAILS}

Samuel Mateus, Ph.D., is professor of media discourse in Madeira University and author of 'Publicidade e Consumação nas Sociedades Contemporâneas' and 'Tele-Realidade- o princípio de publicidade mediatizado'. He has edited with Cintra Torres, Multitudes and Crowds: Collective Action and the Media (2015). He is researcher in Labcom.IFP and ICNOVA.

Contact: Universidade da Madeira, Gab.1.44, Campus Universitário da Penteada, Caminho da Penteada, 9020-105 Funchal, Portugal.

E-mail: samuelmateus@uma.pt

Samuel Mateus has asserted his right under the Copyright, Designs and Patents Act, 1988, to be identified as the author of this work in the format that was submitted to Intellect Ltd. 


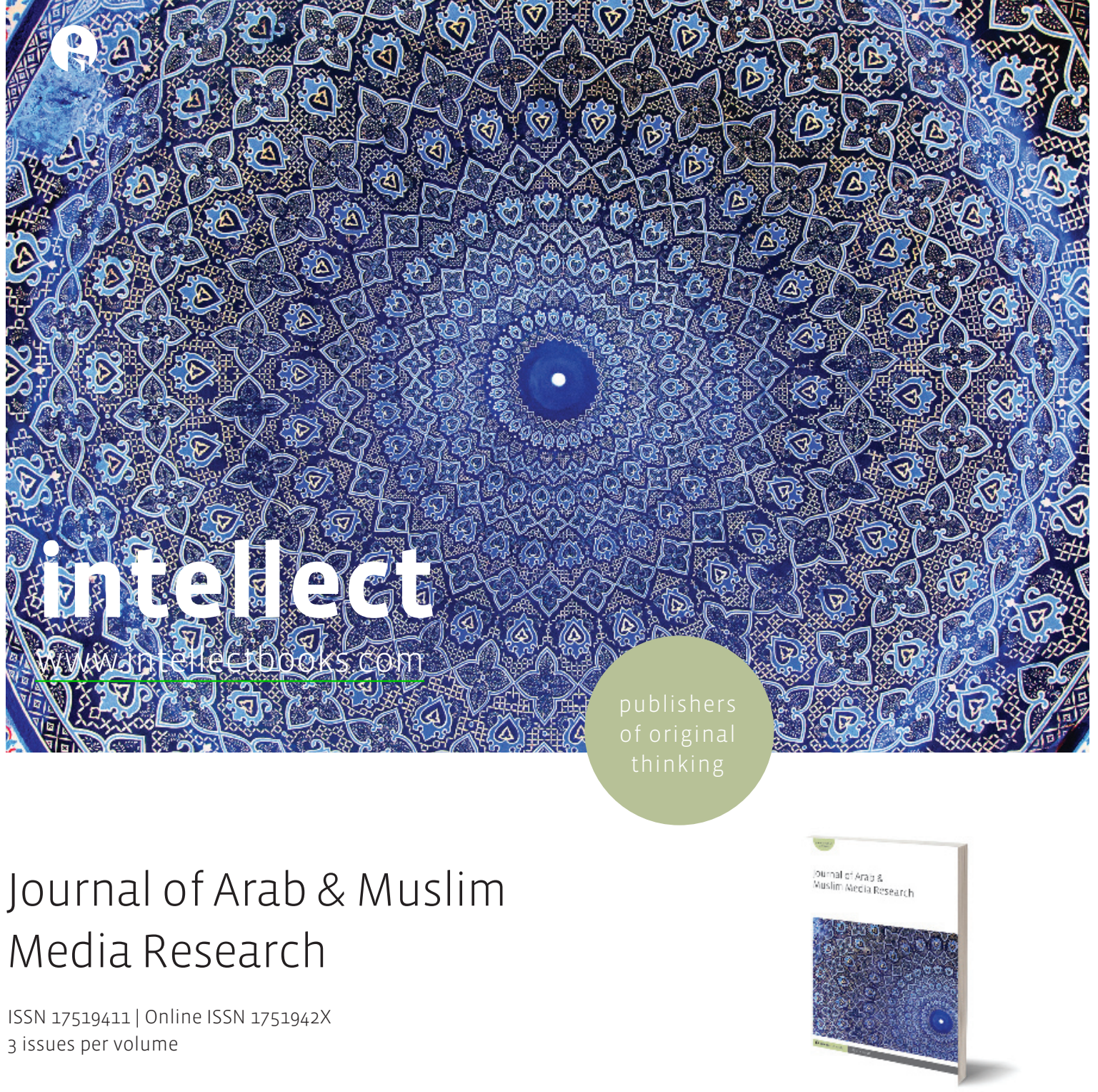

The emergence of satellite TV, the internet and digital technology have dramatically changed the way audiences receive information and interact with the media. The sudden success of Al-Jazeera and other Arab broadcasters have altered the way the Arab world narrates itself and reports news from the region to the rest of the world. The journal aims to lead the debate about these emerging rapid changes in media and society in Arab and Muslim parts of the world.

The Journal of Arab and Muslim Media Research is a refereed academic publication dedicated to the study of communication, culture and society in the Arab and Muslim world. It aims to lead the debate about the rapid changes in media and society in that part of the world. This journal is also interested in diasporic media like satellite TV, radio and new media especially in Europe and North America. The journal serves a large international community of academics, researchers, students, journalists, policy makers and other members of the public in the West as well as the Arab and Muslim countries. 